\title{
Structural Change, Vested Interests, and Scandinavian Energy Policy-Making: Why Wind Power Struggles in Norway and not in Denmark
}

\author{
Espen Moe*
}

NTNU Social Research AS, Department of Sociology and Political Science, Norwegian University of Science and Technology, N7491 Trondheim, Norway

\begin{abstract}
The article takes a theoretically informed look at why policies favoring renewables (here wind power) are implemented in some countries rather than others, with empirical data from Norway and Denmark. The theory combines Joseph Schumpeter and Mancur Olson, emphasizing structural economic change as all-important to long-term economic growth, but that vested interests may easily hamper the growth of new industries, like renewables. Typically, vested interests tied in with the old industrial paradigm seek to preserve their advantage, securing for themselves favorable regulations and institutions. These regulations and institutions do however not necessarily fit new and upcoming industries. The article juxtaposes the experiences of Norway and Denmark. Norway, with its powerful petroleum industry has fed vested interests and built institutions to support the already existing industry, to the detriment of renewables. Denmark, lacking a fixed industrial energy structure, used the 1970s oil crises to build a new structure, based around renewables. Both cases support the theory, suggesting that vested interest structures serve as powerful influences on energy policy.
\end{abstract}

Keywords: Structural change, renewables, wind-power, energy policy, vested interests, Schumpeter.

\section{INTRODUCTION}

Over the past decades Norwegian growth has been greatly fuelled by oil and gas. Norway consciously pursued a policy of structural economic change, building a petroleum industry dominated by domestic companies, and has undoubtedly benefited from it. But could it be that the existence of a huge petroleum industry is a problem for renewables, locking the country into an industrial status quo doomed to fail as remaining fossil resources deplete and as climate change makes petroleum ever less acceptable? What happens to renewables in a country dominated by oil and gas?

Countries that rely for too long on one or a few core industries inevitably fail. But new industries based on new technologies will not appear just anywhere. They may well appear in other countries, as old leaders have invested so heavily in existing industrial and institutional structures that change does not anymore easily occur. Hence, while renewables may be the way forward, they may not become successful in any one particular country, like Norway.

Denmark chose a different course. While now selfsufficient in petroleum, ${ }^{1}$ in the 1970 s it faced a choice between importing its energy or finding alternative means of production. With nuclear power a political taboo, and

*Address correspondence to this author at the Havstadvegen 13B, N7021 Trondheim, Norway; Tel: (+47) 97656678; E-mail: esp.moe@ gmail.com

${ }^{1}$ In 2003 oil accounted for $40 \%$ of Denmark's total primary energy supply. Since 1998 the country has been self-sufficient in oil and gas [1]. without vast amounts of hydropower (like Norway), the 1970s oil crises set Denmark on a course to become one of the world's foremost producers of wind power, deriving almost $20 \%$ of its electricity consumption from wind [2, 3]. At current rates, wind power is rapidly becoming Denmark's largest export industry. These Scandinavian neighbors have produced very different kinds of structural change.

The article tries to do two things. The first section outlines a general framework for long-term economic growth and development, with the onus on Schumpeterian growth. In the process, it substantiates the credentials of renewables as a future growth industry and its potential in constituting a future economic wave of growth. The second section seeks to apply this framework to Norway, showing that prospects for industrial success in renewables are modest, because of the influence that the vested interest structure has over energy policy. The very different development of Denmark serves as a counterpoint. Here, vested interests have played into the hands of renewables. Conforming to theory, the article shows how vested interest structures can be a powerful break on structural change, as here with respect to renewables.

\section{THEORY, LITERATURE AND METHODOLOGY}

\section{Schumpeterian Growth, Renewables And Structural Change}

Structural economic change is essential for long-term growth and development, typically stemming from revolutionary technological change. Hence, this article deals with Schumpeterian growth, that is, growth based on increases in the stock of human knowledge and technological innova- 
tion. ${ }^{2}$ This is because traditional neoclassical economic theories only account for a modest amount of recorded long-term growth and are not well suited to explaining technological change, and because economic analyses routinely attribute such significant portions of growth to technological progress that this itself justifies a focus on Schumpeterian growth. ${ }^{3}$

The Schumpeterian perspective specifically privileges certain core activities, with structural change key. Technologies come and go, and economic activities that brought success in the past are unlikely to do so in the future. Empirically, economic cycles have a lifespan of 50-60 years [6]. Countries that have mastered the core technologies of a particular era, and been successful in setting up industries employing these technologies, are the ones that have forged ahead, grown in power, stature and economic strength [7]. Different scholars tell different versions of the story, but the basic elements remain the same. ${ }^{4}$

However, predicting future growth industries is inherently tricky. Schumpeter was not averse to state interventionism, but was skeptical about politicians picking winners. ${ }^{5}$ To him intervention must be adapted to the particular circumstances of time and space, and financial support cannot serve as an excuse for upholding inefficient industrial practices. ${ }^{6}$ The policy effect must be one of aiding the adjustment to structural change [17]. While skepticism about picking winners is healthy, we know one thing about the future with a lot of certainty: It will bring physical constraints on growth, suggesting a bright future for technologies and industries able to circumvent such constraints. Hence, among the future growth industries are bound to be those that enable us to increase energy supply without releasing greenhouse gases, and industries that reduce energy consumption. First, while the price of oil has fluctuated considerably since peaking at $\$ 147 /$ barrel, it remains on a far higher level than only a few years ago. At current rates, oil consumption will increase by $24 \%$ (from 2008) by 2030, from a current 85 million barrels per day $(\mathrm{mb} / \mathrm{d})$ to $105 \mathrm{mb} / \mathrm{d}[20,21]$. Second, oil reserves will

\footnotetext{
${ }^{2}$ Thus, there are several types of economic growth [4]: 1) Investment-led, or Solovian growth occurs when capital accumulates more rapidly than the growth of the labor force, leading to higher output per capita through increased productivity. 2) Smithian growth is based on commercial expansion and also known as gains from trade. 3) Growth based on scale or size effects. Without downgrading the importance of these (and while recognizing that growth always has several components), the focus here is on 4) Schumpeterian growth.

${ }^{3}$ See for instance [5]: For the G-5 countries (US, Japan, Germany, France, Great Britain) $50-75 \%$ of post-war aggregate real output growth was due to "technical progress".

${ }^{4}$ There is considerable agreement on sectors, industries and time periods. Freeman and Perez [6] identify five technoeconomic paradigms, starting with the Industrial Revolution, based around cotton textiles, iron, steel and electricity (including chemicals), oil and "consumer durables" (notably automobiles), and computers and microelectronics. Similar sectors can be found in [8-15]. For a theoretical and empirical elaboration, see [16].

${ }^{5}$ Schumpeter felt that politics was business, politicians reduced to political entrepreneurs searching for "policy innovations" to satisfy the needs of particular interest groups so as to win the political game [17].

${ }^{6}$ Thus, he would have been far more partial to Danish feed-in-tariffs than the US system during the California Wind Rush, where generous tax credits were directed simply towards the installing of turbines, with no incentives for manufacturers to unduly test their equipment or develop their technology $[18,19]$.
}

gradually exhaust. While there is little consensus as to how fast, increasing demand implies reserves dwindling at accelerating rates. Today, we consume 2-3 barrels per newly discovered one [20-23]. Third, a new and abundant source of cheap energy has typically been at the core of industrial paradigms $[6,7]$. But oil is now more expensive, and future growth will eventually start depending on other energy sources. Normative and political concerns also come into play: First, energy security is becoming more important: East Asia requires increasing shares of the available oil and the West strives to disengage itself from the Middle East. Second, many countries have already spent heavily on creating an advantage in renewables. Third, because of climate change, domestic and international framework conditions are likely to yield more stringent regulations on polluting industries, including demands for increased renewable energy production. Finally, energy derived from fossil fuels must eventually be replaced. The longer it takes for a transition to get underway, the more brutal it will be. At current rates, by 2030 , we need to replace a volume $24 \%$ larger than today [21], with dwindling reserves and climate change becoming more severe.

Wind power will not be the universal answer. New technology will obviously also yield growth in unforeseen areas. Yet, the prediction that renewables constitutes a cluster of highly promising industries and that sustainability will become more important is a conservative one. There is an abundance of figures suggesting that this is happening, even if the financial crisis hit hard. ${ }^{7}$ Some analyses $[18,27]$ even suggest that underfunding is why renewables has not yet become as economical as fossil fuels, and that for instance nuclear is far more expensive than renewables, once you take hidden costs into account. ${ }^{8}$ While starting from a small base, ${ }^{9}$ growth figures are impressive. Since 1997 wind power capacity has increased by more than $20 \%$ every year, and by $27 \%$ a year between 2004 and 2009. Grid-tied solar PV has increased by $60 \%$ a year (2004-09), whereas annual investment in renewables in 2009 reached $\$ 150$ billion, up from $\$ 20$ billion in 2004. In both 2008 and 2009, the US and Europe added more power capacity from renewables than conventional sources. China is the new leader with a total of nearly $45 \mathrm{GW}$, practically doubling its capacity every year since 2005, and in 2010 installing more new capacity than the rest of the world put together. The US is second and Germany third. However, in terms of capacity per capita, per land area, and per GDP, Denmark is the world leader [2426].

\footnotetext{
${ }^{7}$ In 2010 investments in renewables decreased in many parts of the world. For the first time in over two decades the market shrank compared to the previous year. Without China, the world market would have shrunk by one third [24].

${ }^{8}$ Estimates on the potential progress of renewables typically plots performance against time. However, plotting performance against cumulative investment instead shows that wind power has exhibited far bigger improvements per dollar invested than other sources of energy. Iida strongly asserts that in Japan, wind power is competitive with nuclear on price once a number of omitted costs are taken into account [27, 28].
}

${ }^{9}$ In 2008, the renewable energy share of global final energy consumption was $19 \%$. However, out of this wind, solar, biomass and geothermal account for a mere $0.7 \%[25]$. 


\section{The Role Of The State, Institutions, And Vested Interests}

While renewables is becoming more competitive, the power and influence sunk into existing institutional structures may easily prevent just any country from benefitting from this. Structural economic change routinely meets with resistance from vested interest structures, and opposition against new technology is widespread [4]. Typically, as an industry becomes economically prosperous, it grows politically influential, seeking arrangements that serve the industry. But institutional structures and framework conditions suited to established industries do not necessarily suit upcoming industries. Institutions create stability. They are the rules of the game, leading to path-dependencies, acting as bulwarks against radical change [29-31]. Unwittingly, old industries may easily hinder upcoming industries by influencing the institutional framework so that it locks established industries in with advantages that newcomers cannot compete with $[4,16,31] .^{10}$ Thus, Norway's poor performance within wind is governed by institutions and vested interests set up to deal with petroleum. Denmark, without a petroleum industry until recently, serves as a counterpoint.

There is an abundance of descriptive policy-articles on the implementation and diffusion of renewables [33-35]. There is also a substantial literature on Denmark, e.g. [19, $36,37]$. Far less has been done on Norwegian wind power e.g. $[2,38]$, even if there is a literature on Norwegian energy and climate policies, e.g. [39, 40]. However, few attempts have been made at inscribing renewables in the theoretical and historical context that it belongs. Eikeland and Sæverud [33] do a good a job of comparing underlying drivers of renewables in high- and low-diffusion countries, pointing to countries with unsolved energy problems or abundant renewable resources as the successes. But their data are not inscribed in any theoretical framework. Buen [2] comparing Danish and Norwegian wind power policies provides an admirable attempt at summarizing potential explanations why the two have ended up with such different wind power structures, but he also has no overarching framework to help us understand energy policy more generally. There is also a considerable innovation systems literature, Fagerberg, Mowery and Verspagen's [41] volume on Norway a recent contribution. But while scholars have described innovation systems from different historical epochs (e.g. [42, 43]), it also tends towards the descriptive rather than the theoretical.

Hence, what this article is not is a summary of Norwegian and Danish wind power policies. Instead, it is an attempt at inscribing wind power into a more general theoretical framework, focused around vested interest structures. Providing such a framework, Unruh $[44,45]$ contributes a notion of carbon lock-in, providing an explicit focus on fossil fuels through a so-called carbon techno-institutional complex (TIC). TICs are why cost-effective technologies do not defuse more rapidly, locking other technologies out through public institutions and government involvement. Worldwide, governments are for instance subsidizing fossil fuel industries by $\$ 200$ billion a year. Escaping TICs often requires major external shocks or crises, and a solid social mandate. It requires technological change, but first and foremost social and institutional change; incrementally treat-

\footnotetext{
${ }^{10}$ The classic exposition of this argument can be found in Schumpeter [32].
}

ing the main problems of the system (end-of-pipe), modifying the system, but leaving the architecture (continuity), or replacing the entire system (discontinuity) [44, 45]. The latter is obviously the harder to achieve.

Unruh complements Schumpeter. The Schumpeterian economy is characterized by 50-60 year economic cycles, driven by growth in one or a few leading industries. As they saturate, the economy drifts into structural depression ultimately only resolved as new growth industries provide a new industrial engine. The world economy goes through "waves of creative destruction' $[32,46]$. Depression leads to the destruction of old firms and industries, but also to the creation of new ones. New technologies and industries often have other requirements than the old ones, and the degree to which these are met is crucial for long-term growth and structural change. This requires a set of institutions compatible with and supportive of the new technologies. Institutions well suited for an earlier paradigm may be completely inappropriate for the new one $[6,44,45,47,48]$.

Mancur Olson [31] explains why Schumpeterian waves do not just smoothly replace each other. Over time, a silting up of vested interests causes rigidities, slowing growth down. When technological change is allowed to take place, Olson's silting up of institutional rigidities will not occur. When creative destruction is blocked, it will. This provides a role for the state in preventing technological progress from creating the forces that will eventually destroy it. The state needs to promote and protect new technologies and industries while young and vulnerable, but also prevent them from becoming so influential that a few decades later they themselves have a vested interest in blocking structural change. However, going against vested interest structures is politically risky. Hence, such decisions will typically occur only with a solid social mandate $[16,45]$.

The historical record is littered with cases of vested interests hampering growth [16]. The more a country depends on one or a few industrial clusters, and the greater their dominance, the more likely that the state grants them the arrangements that they desire. Ultimately, the driving force in Schumpeter's theory is the entrepreneur. He is the agent of change who breaks the status quo, who sees industrial and economic opportunity rise from structural chaos, and who cannot be explained by "normal" neoclassical economic rationalities. But Schumpeter's hero always exists in an institutional context, and institutional change is slow and difficult. Discrepancies between institutional and economic change are frequent and perfect matches between institutional and economic structures distinctly rare. It is the institutional inertia that Schumpeter's entrepreneur battles. Thus, crucial is that some economies are more open for change than others, enabling the process of creative destruction to run more smoothly [17]. The role of the state is one of pragmatically keeping the economy open for change, so as to make it more likely that the entrepreneur may perform his innovative magic.

The article is an attempt at making theoretical sense of Norwegian and Danish wind power policies by pulling together the empirical and theoretical in a general framework of growth and development. The emphasis on vested interest structures in determining energy policy provides for a distinct role for the state, enabling us to single out indicators 
through which we can determine to what extent the state has managed to keep the economy open for change and vested interests at bay in pursuing energy policy. Vested interest structures as opposed to merely vested interests, indicates that I am interested in more than merely groups lobbying for their narrow interests. Concrete interest groups are an obvious part of the structure, but it also consists of the institutions that have sprung up around the main vested interests and of the routines that these operate according to. It is the existence of a vested interest structure that makes structural change so hard to accomplish. The below indicators thus include structures, routines and actors.

With Schumpeterian theorizing focused on knowledge and innovation, human capital is an obvious indicator. Without this, it does not matter if the state is open for change, as the human capital required to exploit it would not exist. Thus, in a state with strong vested interest structures, I expect human capital to be biased towards these interests. Institutional structure is also obvious: with economic power comes political influence. A state dominated by vested interests is one where the institutional apparatus favors these interests. These are some of the most powerful breaks on entrepreneurship and structural change. Thus, entrepreneurial actors have been included here, as the existing institutional structures to a large extent determine whether their activities come to fruition or not. Third, cost effectiveness flows from how the state's non-neutrality manifests itself in specific routines. While there may be a multitude of routines, an obvious one is that a state dominated by vested interests is expected to have a preference for cost effectiveness as this benefits those actors that have already had time to grow and mature. Fourth, going against vested interest structures is politically risky. Without a social mandate, or social cohesion - as in a widespread belief that public institutions are legitimate and that politicians act in the best interest of the people - decisions upsetting the status quo soon lead to the government being voted out of power [16, 45]. Thus, with structural economic change, public opinion constitutes a very important "actor". In a country dominated by vested interests, we should expect major parts of public opinion siding with these interests. Fifth, while vested interest structures is the organizing theme of the article, this final section looks at their most concrete manifestation, namely specific vested interest groups.

While no exhaustive list of indicators, it is well founded in theory, it flows from the Schumpeterian framework, and is well suited to dealing with the empirical reality. Methodologically, I employ a combination of historical and comparative methods, tracing and comparing energy policy in Norway, with Denmark as a counterpoint to highlight the differing outcomes. The historical method traces the hypothesized causal mechanism. This is combined with Mill's [49] Method of Difference to seek out strategic differences between the two. For Norway, additional data has been acquired through a set of semi-structured interviews with people within wind power industry and research. While no conclusive test, the article serves as a plausibility probe [50], increasing the theory's plausibility and enhancing its prospects ahead of more rigorous testing. For a far more elaborate treatment of the theoretical and methodological framework, see [16].

\section{OIL AND GAS VS. RENEWABLES?}

Acknowledging the dominant role of oil and gas in the Norwegian economy is easy, as is its powerful political connections. Likewise, there is no doubt that Danish wind power has had more beneficial growth conditions than in Norway. But how has this affected other industrial sectors? The theory provides one straightforward prediction; that vested interest structures is the key factor behind the relative failure and success of Norwegian and Danish renewables. In Norway, wind power was always on the outside, whereas in Denmark it ended up on the inside of the vested interest structure.

For Norway, industrial structure itself suggests a bias petroleum accounts for $25 \%$ of GNP (2006) [51]. It makes intuitive sense that petroleum has been allowed to influence energy policy, indirectly affecting the paltry Norwegian performance in renewables. ${ }^{11}$ Despite a good wind resource base, Norway only has a small amount of installed wind power and has consistently lacked a secure long-term support framework. The government offers a subsidy of 8 $\emptyset \mathrm{re} / \mathrm{kWh}(€ 0.01)$ of produced electricity. This makes Norway third from bottom in Europe [52-54]. The unanimous answer from wind scholars and the wind power industry is that the subsidy would need to be twice as big for any large number of installations to be built. The current level is making it impossible to fulfill the government target of an additional 30TWh of renewable electricity by 2016 (compared to 2001). ${ }^{12}$ And the goal of $3 \mathrm{TWh}$ of installed wind power by 2010 has been abandoned [1, 56-58].

The 1972 founding of Statoil through a unanimous decision in the parliament, with the right to $50 \%$ participation on all new petroleum concessions and with borrowing backed by government guarantees, represents Norway actively pursuing structural change. Norwegian companies Statoil, Norsk Hydro and Saga received most of the promising concessions out of a desire to provide the Norwegian oil industry with beneficial conditions. Even with membership in the European Economic Area, foreigners were left in little doubt that Norwegian companies retained certain advantages [51, 5961].

Social scientists and conservative politicians have argued that Statoil grew too large for a small country. The main criticism came from people like former conservative Prime Minister Kåre Willoch (1981-86), describing Statoil as a state inside the state, pushing economically unviable projects at the expense of the state, courtesy of political and industrial allies; using its growth rates to justify its own advice as infallible and ignoring the obvious advantages conferred to it by the state; and that less privileged companies could never have done the same thing $[60,62,63]$. The general accusation against the petroleum sector is that it has used the state to sponsor projects in its interest to such an extent that Norway has ended up with an oil-industrial complex" [61].

The Danish industrial structure has been more conducive to wind power despite the Danish technical potential for

\footnotetext{
${ }^{11}$ Several informants pointed to how the Norwegian industrial structure in itself suggests a bias. The petroleum sector is simply too big, important and dominant for other industrial actors to compete with.

${ }^{12}$ Ane Brunvoll of Bellona states that this has led to 9 out of 10 wind power projects being canceled [55].
} 


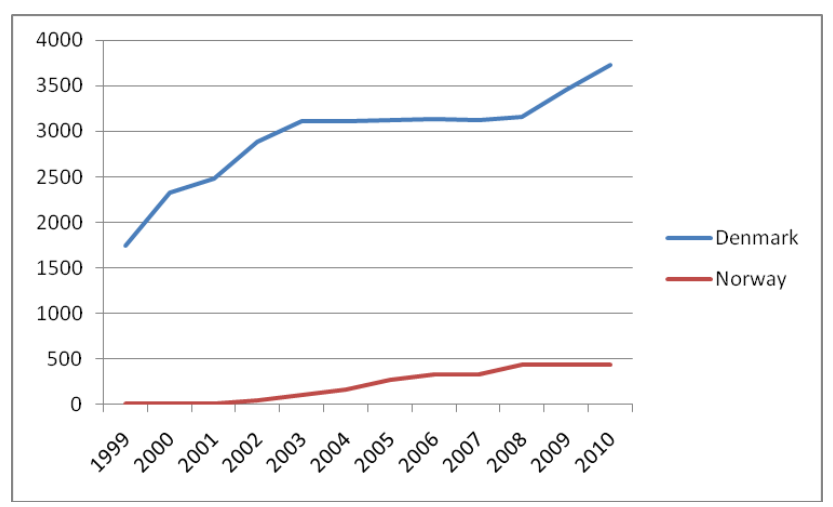

Fig. (1). Cumulative Installed Wind Power Capacity (MW), 1999-2010. Sources: [24, 54, 68].

Table 1. Norwegian and Danish Wind Power Figures

\begin{tabular}{|c|c|c|}
\hline & Norway & Denmark \\
\hline \hline Employment & $200-300^{\mathrm{a}}$ & $25,000^{\mathrm{b}}$ \\
\hline Turnover (million $€$ ) & $25-40^{\mathrm{a}}$ & $7400^{\mathrm{b}}$ \\
\hline Share of electricity consumption $(2007)$ & $0.77 \%^{\mathrm{c}}$ & $19.7 \%^{\mathrm{c}}$ \\
\hline Total capacity (MW, 2010) & $434^{\mathrm{d}}$ & $3734^{\mathrm{d}}$ \\
\hline
\end{tabular}

${ }^{\mathrm{a}}$ Figures from [2].

${ }^{\mathrm{b}}[66]$.

'[3].

${ }^{\mathrm{d}}[24]$.

wind power being less than half that of Norway. ${ }^{13}$ However, energy security issues fueled the first wind power initiatives. Nuclear met with massive public resistance and was never seriously considered [2, 33, 37]. Instead, Denmark "engaged in what is probably the most ambitious support scheme for renewable energy technologies ever seen"'[1].

Not having an energy champion of its own, Denmark not only sought to satisfy its energy needs by other means, but built a home-grown industry in the process. Norwegian wind employs a mere 200-300 people, with a turnover of $€ 25-40$ million, and survives as a subcontractor. Denmark tops 25,000 (down from 28,400 prior to the financial crisis) and $€ 7$ billion [2, 34, 64-66](See Table 1 \& Fig. 1). Danish wind has grown so economically and politically influential that the belated rise of a petroleum industry has had quite different effects than in Norway. Up until the 2001 government change and the 2003-08 period, Danish policies in general (with some notable exceptions) have been predictable, enjoying 25 years of quite broad parliamentary consensus on renewables. After the oil crises, to a far greater degree than in most countries, energy and environmental policy were linked, to such an extent that wind power has itself become a strong structural force and a vested interest, much unlike in Norway where it has not found much stability. In Denmark, strong vested interests stir wind power policies on [2, 37, 67]. And hence, until recently the lack of major rival energy interests has allowed wind to become a strong influence.

\footnotetext{
${ }^{13} 29 \mathrm{TWh}$ and 76TWh/year respectively [2].
}

\section{Human Capital}

Norwegian human capital is biased towards oil and gas. Beyond the industry itself undertaking huge amounts of research, much of the Norwegian Research Council funding is devoted to petroleum rather than renewables, with programs like CLIMIT, GASSNOVA and PETROMAX. There is also a RENERGI program, but major parts of this also goes to petroleum. Also, a very high number of engineering doctoral dissertations are partially funded by Statoil. While there is nothing shady about this, it does mean that traditional institutions of research, learning and education provide partially funded research for those actors that are already the strongest. $^{14}$ Instead, Norway has an innovation system forming around carbon-capture storage (CCS), embraced by both Bondevik and Stoltenberg administrations. Thus, when the KLIMATEK program was established in 1997, promoting $\mathrm{R} \& \mathrm{D}$ in low-emissions technologies, half the budget went to CCS, increasing to three fourths by 2004. CLIMIT's budget is devoted solely to CCS. Amongst high-income countries, relative to GDP Norway has by far the highest funding for CCS [2, 69], but in general Norwegian R\&D falls behind that of other European countries [70]. In renewables, no research hub has emerged, as new, knowledge-intensive industrial ventures have little in common with existing sectors, facing a national innovation system that is not a good fit [71]. Thus, a Norwegian test station was not established until 2003, 25 years after Denmark, and because of the lack of stability in the funding of research on renewables it has been hard to attract industrial partners and investors [72]. Thus, between 1997 and 2007 Norwegian public wind R\&D expenditures amounted to roughly $€ 25$ million as compared to a Danish figure of $€ 131$ million, this probably constituting only $8-10 \%$ of the private Danish R\&D investments [74].

The Danish human capital advantage can be traced back to 1891, when Paul la Cour received parliament support to build a windmill for electricity generation. By his death in 1908, 30 electricity works (partially) driven by wind power had been erected. In the 1950 s, Johannes Juul headed a new wave of developments, culminating with the $1957200 \mathrm{~kW}$ Gedser wind turbine, for many years the world's largest, and a truly pioneering design [18, 75]. Only between 1967 and 1976 has wind power not delivered electricity to the Danish grid [18]. Hence, with the 1970s rise of the modern wind industry, path dependencies had already given Denmark a human capital head start. In 1978 the government established Ris $\varnothing$ Test Station, which rapidly developed into one of the most important wind power research hubs in the world [2, 76], and probably where the effort of the Danish state can most evidently be seen. The initial purpose was to help wind turbine producers onto the market, but its main role soon became one of establishing certification standards that Danish turbines had to live up to. This required considerable

\footnotetext{
${ }^{14}$ One caveat must be added. Stemming from negotiations between the government and the opposition (except for the Progress Party), in 2008 several climate-related programs received a considerable boost, with research in renewable energy getting an extra NOK 70 million ( $€ 9$ million) in 2008, 300 million ( $€ 38$ million) in 2009 and a minimum of 600 million ( $€ 75$ million) in 2010 . Also, NOK 150 million ( $€ 19$ million) was awarded to a demonstration program for the development of offshore windmills and other immature energy technologies [73]. It did however not change the support level for wind power, which remains at $8 \varnothing \mathrm{re} / \mathrm{kWh}(€ 0.01 / \mathrm{kWh})$.
} 
knowledge- and information-sharing between wind turbine producers and the test station, but it also forced dramatic quality improvements of Danish turbines, which in turn gave Danish manufacturers significant advantages abroad [19, 75]. ${ }^{15}$

Ris $\varnothing$ supports a number of public research programs and works tightly with the industry. Denmark still represents "a unique hub of skilled laborers and an experienced network of key components suppliers to support turbine manufacturers" [34]. The Indian company Suzlon is only one of several manufacturers to have located its headquarters here, even if it does not plan to sell turbines in Denmark. The critical mass of technology, industrial resources and research is world class. Some may have allocated more money to R\&D for wind turbine development. Yet, the Danish effort has been more successful, studies suggesting that R\&D has been allocated more efficiently among smaller companies, with a greater variety of turbines and technical solutions. The Danish approach has been bottom-up, building on already existing comparative advantages rather than top-down, as in other countries, that have tried to create industrial giants from scratch. A fortunate human capital advantage also stemmed from the rise of wind power coinciding with the fall of several agricultural companies, which utilized their knowledge in machine production to diversify into wind turbines, using their supplier networks and capital base to become the cornerstone of Danish wind - Vestas, Bonus, Nordtank [2, 18, $19,34,76]$.

Concerns have been raised that the Danish lead is evaporating, and that Denmark is not doing enough. Danish wind is in constant need of new graduates ${ }^{16}$ and is warning against an impending system shift, as in the scaling up of wind power in terms of size and mass production and the growth of wind power giants and markets outside of Denmark. Further, the networks and cooperation so central to the early phase of the industry are no longer equally obvious, and the relationship between academic $R \& D$ and the industry not as close. Also, the pace of development is currently so fast that academic research has difficulties keeping up [19, 64, 74, 76, 77]. Yet, compared to Norway, Denmark is far ahead, in terms of human capital, research funding, links and networks.

\section{Institutional Structure}

The institutional structure is a major Norwegian bias in favor of petroleum. Let us overlook the fact that Norway has an Oil and Energy rather than an Energy Department. It made sense for the state to support the rise of a Norwegian petroleum industry in the 1970s. The Oil and Energy Department (OED) should instead serve as an indication of what is institutionally feasible, and how the state can alter structures so as to make them conducive to the needs of the most important economic actors.

\footnotetext{
${ }^{15}$ In addition to Ris $\varnothing$, the Technical University of Demark and Aalborg University have also developed into valuable wind power research hubs [77].

${ }^{16}$ In 2007, 60\% of Danish wind power companies experienced recruitment problems [65].
}

Experts constitute one institutional bias. The size of the petroleum industry makes it a powerful source of technical, economic and political advice, furthered by an institutional structure consisting of the OED and the Norwegian Petroleum Directorate (OD). These to a large extent are allies of oil and gas. The industry recruits from the bureaucracy, and the state tends to look for people with industry connections. Careers frequently start at the OED, gather pace within the industry, before ending back in the bureaucracy. Many OD employees consider it their task to promote the interests of petroleum and stomping actors that side against it [40, 61, 78, 79].

Institutions that might instead speak on behalf of renewables - the Environmental Department (MD) and The Norwegian Pollution Control Authority (SFT) - are far less influential and tend to be overruled. In an interview with the newspaper Aftenposten [80], previous head of SFT, Håvard Holm commented that whereas the climate section of SFT has $10-12$ people and less than NOK 1 million (€125,000) a year for independent analysis and investigations, the OED, the OD, Petoro, ${ }^{17}$ the Norwegian Water Resources and Energy Directorate (NVE), the oil companies, etc. have staffs of hundreds of highly qualified people. Further, neither the MD nor the SFT have traditionally been strong on climate policy. These were institutions erected at a time when climate change was still a fanciful theory. Their expertise has rather been on toxins and pollutants [40, 78].

Petroleum policy has increasingly been defined as technical problem solving devoid of political content. Instead, it is renewables that has had to justify its existence. It is clear who is formally in charge of petroleum policy, but no singular department has sole responsibility of environmental policy. This has enabled the OED to prevent measures that go against petroleum [40], siding with the industry, arguing that Norwegian $\mathrm{CO}_{2}$-emissions are minuscule. ${ }^{18}$ The same point was made by Frederic Hauge of environmental organization Bellona, who in 2007 blasted the government for having no control over the OD [81]. In contrast, sustainable development is treated as an economic notion, belonging to the realm of economics, not environmental politics [40]. And so, there is no department in charge of coordinating environmental, energy and industrial policy. This is the kind of cross-boundary institution that would have benefited renewables.

My informants did not generally perceive of petroleum or the government as a problem per se. They all lamented the weak funding, but this was one of only two areas with general consensus that the state was doing poorly, although many would prefer a feed-in tariff to be introduced. Most of the informants would have preferred a continuation of the green certificate proposal introduced by the Bondevik II administration and shelved by Stoltenberg II. More predictable government policies would also be beneficial [82]. The second area is concession applications. This point was made

\footnotetext{
${ }^{17}$ Petoro is owned by the Norwegian state, and manages Norwegian offshore petroleum properties and the State's Direct Financial Interest on behalf of the government.

${ }^{18}$ As late as 1997, the Oil and Energy Minister of the Labor Jagland administration argued that $\mathrm{CO}_{2}$ was not a pollutant and should not be subject to Norwegian pollution laws [40].
} 
strongly by Marius Holm of Bellona and by the IEA [54]. It takes renewables far longer to get a concession application through the bureaucracy than it does oil and gas. An average wind power application takes the NVE one to two manyears. The NVE has three to five man-years to its disposal on wind-, gas- and coal power put together. It takes an average of four to five years to get a wind power concession through. At current rates, it will take 40 years to get through the wind power applications currently in the system [83, 84]. This is a very significant brake on the development of wind farms.

The Danish institutional structure has been far more conducive to growth in renewables. The Ministry of Energy has been coordinating wind power since 1980, launching further long-term planning initiatives in 1990 and in 1996. All three initiatives named specific goals with respect to the share of electricity produced by wind [2]. Throughout the 1990s promoting renewables was a primary energy objective. More recently (2006), the partnership Megavind was formed as an attempt to create an institutional structure to facilitate innovation within Danish wind power, gathering all the major players of the innovation system and preserving the Danish advantage by creating a coherent strategy for wind power innovation and research [76, 85].

The Danish administrative structure is obviously less geared towards petroleum. The history of Danish departmental reshuffles does however make it evident that certain issue-areas have not fitted well into sectoral departments. From 1973 to 1994, the Department of Environment had close connections with the Department of Energy, which in 1994 became the Department of Environment and Energy. This reflected the fact that after the 1970s oil crises, energy policy to a great extent was synonymous with environmental policy. However, in 2001 energy policy was moved to the Department of Economics and Industry, reflecting another policy change, away from renewables towards "old industry" [67]. In 2005, energy was put under the Department of Transport and Energy, and from 2007 under the new Department of Climate and Energy, absorbing issue-areas formerly belonging to the departments of Environment, and Transport and Energy. This included energy legislation. The Danish Energy Agency also moved from Transport and Energy to Climate and Energy. Until 2001, the institutional structure was geared far more towards wind power than in Norway. Still, portraying Danish policy as something akin to Japanese MITI-like planning on the part of the state is wide of the mark. Rather, many of the initiatives have come from reacting to economic and technological developments and to opportunities abroad, but they have typically been pro-wind $[18,19,77]$. The rise of the modern industry was driven by private, independent entrepreneurs - innovative and charismatic people with a strong belief in the industry's prospects. Only then did politicians start taking an interest, both as an answer to the energy crisis and as an alternative to nuclear. Yet, the one top-down attempt (1981-89) at creating a national champion, Danish Wind Technology, owned one third by the state, flopped and was eventually taken over by Vestas [18].

A wind power support system was rapidly erected, establishing capital grants for installation of turbines and the right to deliver electricity to the grid at a fixed price per $\mathrm{kWh}$. But Denmark also got lucky. The 1980 California Wind Rush provided them with the world's first major commercial market. From 1982, Denmark supplied the majority of the foreign wind turbines installed. While the timing was lucky, the quality of Danish turbines - a virtue of Ris $\emptyset$ - meant that they were highly competitive. But between 1986, when the California program ended and 1990, it also led to a near wipe-out of the Danish industry. The entire industry restructured, and only Vestas, Nordtank, Micon and Bonus narrowly survived [18, 19, 75].

Despite notable ups and downs, compared to most countries, Danish energy policy enjoyed considerable consensus (particularly between 1990 and 2001). It provided the industry with long-term planning scenarios and a solid base for decision-making $[77,86]$, which meant that when Danish entrepreneurs made their forays into wind, no major institutional structures impeded upon their progress. Instead, luck, Denmark's energy situation, and path-dependencies in wind power and machine production, meant that an institutional structure receptive to the needs of wind grew much faster than in Norway. While the Norwegian industry has always stood on the outside of the institutional structure, Danish wind quickly ended up on the inside.

The Danish concession system also diverges considerably from the Norwegian. For smaller installations, concessions are left to the local municipalities (granted that technical requirements are fulfilled). The process is highly decentralized, far faster than in Norway, ${ }^{19}$ and one of the keys to Danish success [86, 87]. In 2008, a grand bargain involving the major political parties further emphasized the decentralized approach by making implementation less top-down and increasing the benefits for the municipalities [65, 88]. While far from perfect, Danish institutions have consistently promoted renewables.

\section{Cost Effectiveness}

Cost effectiveness is an obvious example of a routine characterizing vested interest structures. It favors existing actors, as these are the ones that have had time to become cost-effective. With institutional structures, this has probably been the most important influence on Norwegian policy. All informers commented on the unwillingness to think of energy and industrial policy as linked. Instead, the main perspective, pervading all major departments is the notion of cost effectiveness. Even the MD has adopted a discourse of cost effectiveness so as to be taken seriously [40]. In the 1980s and -90s this hamstrung Norwegian wind [38].

Cost effectiveness may seem like a good compass. However, cost effectiveness plays right into the hands of established industries. ${ }^{20}$ The climate change approach of the OED has adamantly been one of cost effectiveness. Also, the department has been strongly affected by the emphasis on cost effectiveness urged upon it by the petroleum industry. The

\footnotetext{
${ }^{19}$ The Risø National Laboratory administers the approval schemes for wind power, created by the Danish Energy Authority.

${ }^{20}$ It could be argued that cost effectiveness is not really the problem, and that structural change can be accomplished by technology-neutral means, for instance through a carbon tax. However, a carbon tax represents a far more visible redistribution of resources than for instance a subsidy to a new industry, and is thus fraught with political risk. (There is also a danger that a steep carbon tax in one country leads to industries flagging out.)
} 
main reason why this is such a good foil for oil and gas, is that it virtually provides a guarantee against major structural change. Thus, the Norwegian climate change approach advocates the flexible mechanisms and joint implementation of the Kyoto protocol. Norway has actively sought to create arrangements that enable it to reduce greenhouse gas emissions where it is cost effective. This is the solution fronted by the economists running the Norwegian departments. Reducing emissions domestically would also put a strain on industry. Hence, from the outset, industry associations lobbied heavily for an approach founded on flexibility, crosscountry solutions and joint implementation. Granted, Norway has had a carbon tax since 1991. But it was successfully fought by the energy-intensive industry, thus about $40 \%$ of the industry is exempt. The oil industry was not lobbying very effectively at the time as Statoil and Hydro did not join forces until 1991 with the Norwegian Oil Industry Association (OLF), and so, oil and gas did not get exempt [39]. The exemptions do however mean that the carbon tax has less of an effect on structural change than it could have.

However, the flexibility mechanisms were very much a result of lobbying, with OLF and The Confederation of Norwegian Enterprise seeking to replace the carbon tax by tradable permits [39]. Combined with technological initiatives on CCS, it would provide for an industrial future where Norway can stick with its existing industrial structure. Oil and gas was not happy about CCS, as it does increase costs. Hence, this political battle was fought and lost and indication that the industry does not always get its way. Yet, for the industry this was a smaller evil than a steep carbon tax, especially as it is to $80 \%$ being subsidized by the state [89].

The implication for renewables is a lack of willingness to see energy and industry policy as linked, and no recognition of a need for structural change, as in the phasing in of nonfossil energy. With Marius Holm [78] of Bellona; it is a system that preserves the existing structure, but makes it slightly more efficient. A heavy emphasis on CCS only pushes structural change farther into the future. Several informants insisted that present-day willingness to support projects longterm in scope is markedly less than in the past and linked to the influx of economists in government departments and the requirement that projects be viable from day one. While wind power is not, simply waiting for the technology to improve and electricity prices to rise effectively means missing out. Technological thresholds must be crossed, and this does not just happen by itself (see also [82]).

The irony is that the one area in which the government has renounced cost effectiveness is in CCS. There is no guarantee that CCS will ever provide energy that is cheaper than renewable energy (unless also applied to coal). ${ }^{21}$ Hence, Norwegian enthusiasm rests on its fit with existing industrial structures. It is a non-cost effective solution to an approach chosen primarily for cost effectiveness reasons. Moen [91] suggests a causal trajectory. Petroleum has increased dramatically in importance in Norway, whereas traditional industry has waned. Simultaneously, industrial policies have deviated from the European norm in being 'neutral' (as in

\footnotetext{
${ }^{21}$ In 2008 Danish climate and energy minister, Connie Hedegaard, commented that CCS is horribly expensive, and that it doesn't look as if it will work until after 2020 [90].
}

left to the market). On-shore industry had to be scaled down to provide room for petroleum. The director of the Bank of Norway in 2002 made it clear that deindustrialization would be useful. This might explain the reluctance of the state, a sentiment echoed by Sven Røst at Scatec: "We have a hard time finding a decent supply of labor. Thus, in some way you could always argue that there is no real need for a state subsidizing renewables."

In Denmark, up until 2001 cost effectiveness was less of an issue. The original drive came from energy security, hence the onus was on energy production and the build-up of a wind power industry, even if it was cheaper to import electricity. ${ }^{22}$ Granted, Danish wind power schemes have been more cost effective than those of other countries in stimulating technological improvement and efficient electricity production, stimulating both demand and supply. Early policies stimulated demand through a demand-side subsidy to cooperatives and private wind turbine buyers. This provided a context for wind power characterized by decentralized bottom-up, relying on existing competencies, where demand from private and cooperative developers created a steady home market. The creation of a domestic market constitutes one of the greatest triumphs of the Danish state, populated by domestic companies Vestas and Bonus/Siemens that have covered $99 \%$ of the market $[1,2,18,34,37]$.

This stands in stark contrast to the Norwegian top-down, large-scale, heavy-industrial focus, based on traditional actors from petroleum and hydropower $[2,38]$. Also, the Norwegian focus has been exclusively on supply, and distinctly short-term, as in stimulating power supply during shortages, rather than any long-term stimulus for industrial development and technological change.

In Denmark, once the initial phase, characterized more by private initiatives than government planning, was over, wind power was singled out by the state, buoyed by the lobbying of the Danish Wind Turbine Owners' Association and the Danish Windturbine Manufacturers' Association and by public support, and stimulated by research facilities. Not overstating the degree of planning on the part of the state, and while not subsidizing suppliers per se, a number of policies and measures were adopted by the state in order to create an increased supply of energy and a strong and independent domestic industry. While these measures have not remained constant, leading to notable stops and starts in wind turbine installation, the commitment to wind has persisted for 25 years and provided the Danish industry with better opportunities than most others $[1,2,18,67,75]$.

However, since 2001, more market-oriented Danish administrations have sought to streamline energy policy along cost effectiveness lines. In 2003, R\&D funding was cut and the feed-in tariff lowered, the argument being that the state should not subsidize a thriving industry. This was accompanied by Denmark, also for cost-effectiveness reasons, now meeting its Kyoto commitments more explicitly through

\footnotetext{
${ }^{22}$ Wind power support has come at a price. With $\mathrm{CO}_{2}$-emissions valued at DKK 270 (€36) per ton, 1990s support for renewables represented a negative investment as a whole. The 1992-99 net present value of subsidies amounted to DKK -3 billion ( $€-0.4$ billion), of which subsidies and preferable taxation DKK 25 billion, environmental benefits DKK 20 billion, and DKK 2 billion from the growth of the windmill industry [1].
} 
emissions reductions abroad. The wind industry has argued that part of the climate problem should be solved through wind power, that no EU country offers lower average prices for wind power (yet higher than in Norway), and that with the old regime Denmark would now be producing one-third rather than one-fifth of its electricity from wind $[1,2,52$, 9294]. The 2008 political bargain included a goal to increase the renewable share of total energy consumption from $15.6 \%$ (2006) to $20 \%$ (2011), with wind power support increased back from 10 to $25 \varnothing \mathrm{re} / \mathrm{kWh}(€ 0.033 / \mathrm{kWh})[65,90] .{ }^{23}$ The degree to which cost effectiveness is now a factor is still unclear. The 2003 policy change led to the almost complete halt to the installation of wind power for five years (see Fig. 1). However, up until then the rise of the industry was not to any major degree influenced by cost effectiveness concerns. And it is still true that since 2000 the value of Danish wind power exports has quadrupled, accounting for $8.5 \%$ of total exports [66]. At the moment, the industry is cautiously optimistic, with installation capacity increasing both in 2009 and 2010.

\section{Public Opinion}

A strong belief amongst all the informants was that local objections make Norwegian politicians reluctant to support renewables. Local nature protection agencies have been skilled at lobbying against wind power, and the impression has spread that wind power is ruining huge chunks of pristine wilderness. While it is hard to make clear judgments as to what extent this has fuelled political reluctance, the informants were adamant and unanimous. ${ }^{24}$ The IEA [54] also notes local opposition as a major Norwegian obstacle.

In contrast, Denmark has been able to rely on local wind support. Nielsen [37] states that turbines are now perceived as an integral part of the cultural landscape. This is partly because Danish wind power has always been a grass-roots phenomenon, stemming from general resistance against nuclear power [18]. More recently, environmental concerns have given local support an additional boost [19, 37]. A study carried out by the Danish Energy Authority et al. [96] shows almost $85 \%$ support for wind power being used "to a great extent". Megawatt [97] cites an ACNielsen study, where $83 \%$ agreed/completely agreed that more wind power should be implemented locally.

In 1992 more systematic planning procedures were developed. Danish wind power developers now put more emphasis on visualization, seeking to minimize the harm done to the landscape [37, 67, 86]. In Norway, windmills have typically been located with power supply and cost effectiveness in mind. Hence, Norwegian wind farms have ended up in exposed and scenic locations, rather than in less exposed locations that would however be more costly and less visually intrusive [2].

Finally, local community benefits have been integral to Danish wind power deployment. Many turbines are owned

\footnotetext{
${ }^{23}$ Turbines connected to the grid after January 1, 2005 were only entitled to a premium of $0.1 \mathrm{DKK} / \mathrm{kWh}(€ 0.013 / \mathrm{kWh})$ until the turbine is 20 years old.

${ }^{24}$ At the same time, a study by Vestlandsforsking [95] concludes that "NIMBYism" was only a minor problem, and only a small minority had concerns about visual pollution.
}

individually or by cooperatives, with a number of Danes direct economic beneficiaries. ${ }^{25}$ Ownership is decentralized, with cooperatives of a few hundred investors typically owning three to five turbines. The latest political compromise is meant to facilitate a greater degree of local participation and less centralized bureaucracy $[2,37,65]$. However, the tendency towards ever larger installations has met with resistance. Hence, one strategy has been to install bigger wind mills and wind parks at sea, away from the public eye. ${ }^{26}$

\section{Vested Interest Groups}

We often think of vested interests only as concrete interest groups. This is another area where there are telling differences. Norway has strong vested interests within petroleum, but not in renewables. There are two fairly weak windrelated organizations. A small and fragmented Norwegian renewable energy industry is a major problem for lobbying, and the ability to affect policy has been slim $[2,98]$. Instead, public opinion on climate change, not wind power, is what has driven the discourse. The government approach overlaps with that of the general industry, in particular by petroleum, i.e. a focus on low carbon taxes or emissions trading, or on reducing emissions abroad. While good for competitiveness, it pushes structural change into the indefinite future.

In Denmark, there are two strong wind organizations. Established decades ago, they have had time to coordinate. They are also not marginalized by industrial or institutional structures, and their effect on policy has been considerable. Granted, a petroleum industry has risen, but wind power interests are already strong. When in 2003 the government sought to alter the course of energy and climate policy along Norwegian lines, massive pressure from wind power in collaboration with the opposition succeeded in creating a crosspolitical bargain staking out a more ambitious policy course. This was reinforced in $2008[2,33,88,93]{ }^{27}$

While one could argue that governmental autonomy, implementing policy independently of vested interests, is beneficial, it matters which interests these are. In the 1970s, Norway building a petroleum industry was a wise policy of structural change. That it also created powerful vested petroleum interests and that Norwegian institutions have been built so as to reflect the needs of this industry is no surprise. However, this is not a structure that can also be expected to be a good fit for wind power. Denmark also has vested interests. There is no a priori way of distinguishing between "good" and "bad" vested interests. Yet, some industries have their best years ahead of them, and for reasons listed earlier it is very probable that wind power is one such industry.

\footnotetext{
${ }^{25}$ In $2002,80 \%$ of Danish wind turbines were owned by wind energy cooperatives and individual farmers [75].

${ }^{26}$ A study by the Danish Energy Authority et al. [96] suggests that the willingness to pay to have wind farms located out at sea (as in $18 \mathrm{~km}$ rather than 12 ) is considerable. It increases by $100 \%$ from 12 to $18 \mathrm{~km}$, and by another $33 \%$ from 18 to $50 \mathrm{~km}$.

${ }^{27}$ However, following long-standing lobbying from DONG Energy, in 2008 the government opened the door for increased use of coal. Hence, other vested interest groups also manage to influence policy. The government argued that intervening would go against EU legislation, which essentially is about cost effectiveness [90].
} 
With that in mind, Danish vested interests seem likely to be more beneficial than the Norwegian.

\section{DELIBERATIONS, MUSINGS AND FINAL CONCLU- SIONS}

In the final analysis, two cases and a loosely defined variable cannot give rise to strong causal reasoning. It can however yield valuable information, as well as theoretically based empirical propositions. The Schumpeterian framework holds. Vested interests proves a fruitful angle from which to analyze energy policy, and the theoretically derived indicators reveal telling differences between the two countries.

\section{An Alternative Norwegian Vested Interest Structure?}

The Norwegian petroleum industry is undoubtedly powerful and does to some extent negatively affect renewables, but there is no evidence of oil and gas actively blocking renewables. ${ }^{28}$ Also, policy decisions have gone against it, like CCS and the carbon tax. But also, Norway has a second major vested energy interest complex. Prior to the oil-industrial complex, the 1950s and -60s saw the rise of a hydroindustrial complex, resulting from the state's political priority on cheap electricity. This could only be done by going extensively against the market and systematically overinvesting in electricity production. And despite fulfillment of the political goals, the sector kept expanding, accompanied by cost overruns and weak oversight from close ties between government institutions, hydropower and energy-intensive industry [72, 99]. Thus, in addition to this second vested energy interest, renewable electricity was already at a level that until recently made other types of renewables redundant, which is one reason why the oil crises did not prompt the same response as in Denmark. ${ }^{29}$

Ironically, the rise of petroleum was what did the most to weaken the hold of hydropower, as the creation of the OED ended the close institutional ties between energy policy and industrial policy [72, 99]. While reorganizing energy and electricity policy so as to include petroleum made sense in the 1970s, today the question is whether a closer connection between energy policy and industrial policy is once again a desirable option.

\section{Off-Shore Wind as a Norwegian Vested Interest Loophole?}

Several informants suggested that Norwegian off-shore wind has more political goodwill than land-based wind. Even if the 2007 climate policy White Paper spends considerably more ink on CCS than off-shore wind [100], there has been optimism within off-shore wind that in due time necessary government support will arrive. This fits far better with the Norwegian institutional and industrial structure, with expertise within off-shore installations and shipping, and is an area where established Norwegian actors are making inroads.

\footnotetext{
${ }^{28}$ Most of the informants stressed that while the petroleum industry receives favorable conditions, to renewables petroleum is neither an advantage nor a disadvantage.

${ }^{29} 99 \%$ of generated Norwegian electricity is produced by hydropower. Hydropower also accounts for half of Norwegian primary energy demand [69].
}

Tellingly, out of 94 companies involved in off-shore wind, $70 \%$ are also involved in petroleum or maritime industry. Only 17 were preoccupied solely with off-shore wind, and 16 were quite small. While most of the recent expansion in Danish wind power capacity has occurred off-shore, and while this is an area into which Denmark has extended its on-shore advantage, the Danish focus has predominantly been on non-floating mills, unlike in Norway [74, 82, 101]. Instead, it is with floaters that Norway may benefit from complementarities with domestic industries. Two publicly financed research centers (Nowitech, Norcowe) focus exclusively on off-shore wind. Yet, early optimism has been tempered by the present oil and energy minister declaring that off-shore wind in Norway will be too expensive, and there are no concrete plans for off-shore mills to be erected. At present, there is a belief that this is an area where Norway will do well, but given the mixed signals from the government, rather by supplying equipment and know-how for a much expected European expansion than through the deployment of off-shore wind on the Norwegian shelf [82].

Enthusiasm for off-shore wind compared to that for the land-based industry is predictable. With Unruh [45], it makes the transition away from carbon lock-in less severe, as the off-shore strategy amounts not to replacing the system (discontinuity), but modifying it (continuity). It is also a marketniche strategy: off-shore wind is populated by companies that are still only testing prototypes. And with respect to the importance of a social mandate, NIMBYism is far less of a problem than with land-based wind.

The enthusiasm also suggests that petroleum is a more influential vested interest than hydropower. The abundance of hydropower meant that Norway lacked the incentive to convert its stationary energy system to wind. Thus, one might not look further for an explanation for the differences between Norway and Denmark. But that does not explain the enthusiasm for off-shore, which is technologically more challenging, requiring a far heavier expansion of existing infrastructure than land-based solutions. No hydro interests seek to influence these developments. Instead, they are enabled by the potential closeness with the petroleum industry: In September 2009, Statoil's Hywind project became the world's first full-scale floating off-shore wind turbine [102]. True, NOK 400 million ( $€ 50$ million) is peanuts compared to their core petroleum activities. It is still an important project, but one that will hardly lead to further expansion without a proper government support regime.

\section{Back To Oil And Gas...}

Indirectly, oil and gas still has major effects on the growth of rival industries, very much akin to what the Schumpeterian framework suggests. The institutional structure is a road map for industrial policy. The current Norwegian structure is highly beneficial to oil and gas, whereas renewables has needs that are not equally met. Renewables might instead have benefitted from an interdisciplinary department with genuine political power.

Cost effectiveness may in itself not be an argument that oil and gas hampers the growth of renewables, as it might 
easily have been the government's stance in any case and the perspectives of government and petroleum merely accidentally overlapping. But this overlooks that without the peculiar Norwegian industrial structure, the need for an industrial policy to such an extent based on cost effectiveness would have been far less heartfelt. It is this structure that makes it so hard for governments to seriously consider major structural change and that makes it more intuitive to subsidize CCS than wind.

Denmark serves as a counterpoint. Strong vested interests within renewables, a strong research effort and the conscientious build-up of a human capital base centered around research hubs of worldwide renown, has meant that this is no longer a new and vulnerable industry. Granted, subsidies are still necessary, and so wind power has still not matured to the extent that support can be relinquished. Also, the reduced price for wind power in Denmark did lead to a very marked stagnation in the deployment of new turbines. Yet, Danish wind power has only intermittently been held back by lack of or unpredictable government support. No major structures have had to be torn down in order to pave the way for this industry, but new structures have been built and institutions created to suit its needs, unlike in Norway.

In terms of causal connections, the article supports the overall Schumpeterian story. It brings two more examples of the explanatory power of vested interests and institutional structures. It shows that it is not enough just to have generally good framework conditions and a good human capital base for business to thrive. Rather, the industrial neutrality propagated by Norwegian economists and politicians is never neutral. Governments who insist on neutrality with respect to new industries are bound to keep favoring the existing actors. For structural change, policy must be implemented to counter neutrality and to provide new industries with proper growth conditions. Norway has ended up with a structure favoring neutrality, Denmark has not. No prizes awarded for guessing which country has been more successful with respect to developing an industry like wind power.

\section{CONFLICT OF INTEREST}

None declared.

\section{ACKNOWLEDGEMENT}

None declared.

\section{REFERENCES}

[1] IEA. Energy Policies of IEA Countries: Denmark 2006 Review; OECD/IEA: Paris, 2006.

[2] Buen, J. Danish and Norwegian wind industry. Energy Policy, 2006, 34, 3887-3897.

[3] IEA. Statistics \& Balances, 2010. Available at: http://www.iea.org/stats/index.asp [Accessed July 14, 2011]

[4] Mokyr, J.The Lever of Riches; Oxford University Press: Oxford, 1990.

[5] Kim, J.I.; Lau, L.J. The Sources of Economic Growth of the East Asian Newly Industrialized Countries. J. Japan. Int. Econ., 1994, 8(3), 235-271.

[6] Freeman, C.; Perez, C. In: Technical Change and Economic Theory; Dosi, G.; Freeman, C.; Nelson, R.; Soete, L. Eds.; Pinter Publishers: London, 1988; pp. 38-67.
[7] Reinert, E.S. How Rich Countries Got Rich and Why Poor Countries Stay Poor; Public Affairs: New York, 2007.

[8] Bairoch, P. International Industrialization Levels from 1750 to 1980. J. Eur. Econ. Hist., 1982, 11(2), 269-333.

[9] Freeman, C.; Louçã, F. As Time Goes By; Oxford University Press: Oxford, 2001.

[10] Hobsbawm, E.J. Industry and Empire; Penguin Books: London, 1969.

[11] Gilpin, R. War and Change in World Politics; Cambridge University Press: Cambridge, 1981.

[12] Landes, D.S. The Wealth and Poverty of Nations; W. W. Norton: New York, 1998.

[13] Modelski, G.; Thompson, W.R. Leading Sectors and World Powers; University of South Carolina Press: Columbia, 1996.

[14] Perez, C. Technological Revolutions and Financial Capital; Edward Elgar: London, 2002

[15] Rostow, W.W. The World-Economy; Macmillan Press: London, 1978.

[16] Moe, E. Governance, Growth and Global Leadership; Ashgate: Aldershot, 2007.

[17] Hospers, G.-J. Joseph Schumpeter and His Legacy in Innovation Studies. Knowledge, Technol. Policy, 2005, 18(3), 20-37.

[18] Jensen, I.K. Marnd i modvind; Børsens Forlag: København, 2003.

[19] Vestergaard, J.; Brandstrup, L.; Goddard, R.D., III. Industry Formation and State Intervention: the case of the wind turbine industry in Danmark and the United States; Nov. 2004; Academy Intl Business Conference Proceedings, USA, 2004, pp. 329-340.

[20] IEA. Energy Technology Perspectives 2008; OECD/IEA: Paris, 2008.

[21] IEA. World Energy Outlook 2009; OECD/IEA: Paris, 2009.

[22] Energimyndigheten. Oljens ändlighet - Ett rörligt mål! ER 2006:21. Available at: http://www.baff.info/rapporter/Oljans\%20Andlighet\%20-\%20ett\%20rorligt\%20mal.pdf [Accessed July 17, 2011].

[23] Tsoskounoglou, M.;Ayerides, G.;Triftopoulou, E. The end of cheap oil. Energy Policy, 2008, 36, 3797-3806.

[24] WWEA. World Wind Energy Report 2010, 2011. Available at: http://www.wwindea.org/home/images/stories/pdfs/worldwindenerg yreport2010_s.pdf [Accessed July 2, 2011].

[25] REN21. Renewables 2010: Global Status Report; REN21 Secretariat: Paris, 2010.

[26] EWEA. Wind in Power: 2009 European Statistics, 2010. Available at: http://www.ewea.org/fileadmin/ewea_documents/documents/statistics/100401_General_Stats_2009.pdf [Accessed July 16, 2011].

[27] Schilling, M.A.; Esmundo, M. Technology S-curves in renewable energy alternatives. Energy Policy, 2009, 37, 1767-1781.

[28] Japan Times. All cost bets off if Big One hits nuke plant. September 5 , 2007. Avaialable at http://search.japantimes.co.jp/cgibin/nn20070905f1.html [Accessed Nov 12, 2010].

[29] March, J.; Olsen, J. Rediscovering Institutions; Free Press: New York, 1989.

[30] North, D.C. Institutions, Institutional Change and Economic Performance; Cambridge University Press: New York, 1990.

[31] Olson, M. The Rise and Decline of Nations; Yale University Press: New Haven, 1982.

[32] Schumpeter, J.A. The Theory of Economic Develoment; Transaction Publishers: New Brunswick, 1983.

[33] Eikeland, P.O.; Sæverud, I.A. Market diffusion of new renewable energy in Europe. Energy Environ., 2007, 18(1), 13-37.

[34] Lewis, J.I.; Wiser, R.H. Fostering a renewable energy technology industry. Energy Policy, 2007, 35, 1844-1857.

[35] Reiche, D., Ed.; Handbook of renewable energies in the European Union; Peter Lang: Frankfurt a.M., 2002.

[36] Kamp, L. Learning in wind turbine development; $\mathrm{PhD}$ dissertation, Utrecht University, Netherland, 2002.

[37] Nielsen, F.B. In: Wind power in View; Pasqualetti, M.J.; Gipe, P.; Righter, R.W., Eds.; Academic Press: San Diego, 2002; pp. 115132.

[38] Solli, J. Kalkylenes retorikk; PhD dissertation, Norwegian University of Science and Technology, Norway, 2004.

[39] Bang, G. Sources of influence in climate change policymaking; $\mathrm{PhD}$ dissertation, University of Oslo, Norway, 2004.

[40] Boasson, E.L. Klimaskapte beslutningsendringer. FNI-rapport, Fridtjof Nansens Institutt: Oslo, 2005.

[41] Fagerberg, J.; Mowery, D.C.; Verspagen, B., Eds.; Innovation, Path Dependency, and Policy: The Norwegian Case; Oxford University Press: New York, 2009. 
[42] Nelson, R.R., Ed.; National Innovation Systems; Oxford University Press: New York, 1993.

[43] Nelson, R.R.; Rosenberg, N. In: National Innovation Systems; Nelson, R.R., Ed.; Oxford University Press: New York, 1993; pp 3-21.

[44] Unruh, G.C. Understanding carbon lock-in. Energy Policy, 2000, $28,817-830$.

[45] Unruh, G.C. Escaping carbon lock-in. Energy Policy, 2002, 30, 317-325.

[46] Schumpeter, J.A. Capitalism, Socialism and Democracy; Harper: New York, 1942.

[47] Gilpin, R. Economic Evolution of National Systems. Int. Stud. Q., 1996, 40(3), 411-431.

[48] Nelson, R.R. Recent Evolutionary Theorizing About Economic Change. J. Ec. Lit., 1995, 33(1), 48-90.

[49] Mill, J.S. A System of Logic; Longman's: London, 1904.

[50] Eckstein, H. In: Handbook of Political Science; Greenstein, F.I.; Polsby, N.W., Eds.; Addison-Wesley: London, 1975; pp. 79-137.

[51] Engen, O.A. In: Innovation, Path Dependency, and Policy; Fagerberg, J.; Mowery, D.C.; Verspagen, B., Eds.; Oxford University Press: New York, 2009; pp. 179-207.

[52] EREF. Prices for Renewable Energies in Europe. Report 2006/2007, 2007. Available at: http://www.erefeurope.org/dls/pdf/2007/eref_price_report_06_07.pdf [Accessed July 17, 2011].

[53] Gemini. Klimahjelp i skiftende vær. 03/2007. Available at http://www.ntnu.no/gemini/20007-03/30-36.htm [Accessed July 17, 2011].

[54] IEA. Energy Policies of IEA Countries: Norway 2005 Review; OECD/IEA: Paris, 2005.

[55] Teknisk Ukeblad. -Latterlig satsing på fornybar energi. 2007, 33, 34-5.

[56] Teknisk Ukeblad. Vindkraft tar av - men ikke i Norge. February 20, 2008. Available at http://www.tu.no/energi/article137812.ece [Accessed July 17, 2011]

[57] Teknisk Ukeblad. Nå er vindstøtten tilbake. April 21, 2008. Available at http://www.tu.no/energi/article154598.ece [Accessed July 17, 2011].

[58] Zero. Sverige gjør det Norge ikke klarer: 3TWh vindkraft innen 2010, August 9, 2009. http://www.zero.no/fornybar-energi/sverigegjoer-det-norge-ikke-klarer-3-twh-vindkraft-innen-2010 [Accessed July 17, 2011]

[59] Hanisch, T.J. Norsk oljepolitikk fra Groningen til Statfjord. Working Paper 2001:8; Working Paper Series: Høgskolen i Agder, Kristiansand, 2001.

[60] Lerøen, B.V. Drops of Black Gold; Prinfo Kai Hansen: Stavanger, 2002.

[61] Ryggvik, H. Oljekomplekset. TMV-senteret, nr 102, 1996

[62] Bould, M.; Hanisch, T.J. "Vingestekkingen" av Statoil. Working Paper 2001: 9; Working Paper Series: Høgskolen i Agder, Kristiansand, 2001.

[63] Willoch, K. Statsminister; Schibsted: Oslo, 1990.

[64] Andersen, P.H.; Drejer, I. Danmark som Wind Power Hub. Vindmølleindustrien, 2006. Available at: http://www.windpower.org/download/856/Danmark_som_Wind_Power_Hub.pdf [Accessed July 17, 2011].

[65] Megawatt. Vindmølleindustriens nyhedsmagasin, June (5), 2008. Available at: http://www.windpower.org/download/119/Megawatt_2008_2.pdf [Accessed July 17, 2011].

[66] Vindmølleindustrien. Branchestatistik 2011. Available at: http://www.e-pages.dk/windpower/23/ [Accessed July 14, 2011].

[67] Krohn, S. Wind Energy Policy in Denmark Status 2002. DWIA 2002. Available at: http://windpower.customers.composite.net/media(492,1033)/Wind_energy_policy_in_Denmark:_Status_2002.pdf [Accessed July 17, 2011].

[68] GWEC. Global Wind Report, 2005. Available at: http://www.gwec.net/fileadmin/documents/Publications/GWECGlobal_Wind_05_Report_low_res_01.pdf [Accessed July 4, 2011].

[69] van Alphen K; van Ruijven J; Kasa, S; Hekkert, M; Turkenburg, W. The performance of the Norwegian carbon dioxide, capture and storage innovation system. Energy Policy, 2009, 37, 43-55.

[70] Senter for Fornybar Energi. FoU-stratgi for fornybar energi.SFFE. NTNU, SINTEF, IFE, 2007.

[71] Fagerberg, J.; Mowery, D.C.; Verspagen, B. In: Innovation, Path Dependency, and Policy; Fagerberg, J.; Mowery, D.C.; Verspagen, B.Eds.; Oxford University Press: New York, 2009; pp. 1-29.

[72] Christiansen, A.C. New renewable energy developments and the climate change issue. Energy Policy, 2002, 30, 235-243.
[73] forskning.no. -Klimaforlik i riktig retning, 2008. Available at: http://www.forskning.no/artikler/2008/januar/1200577040.5 [Accessed July 4, 2011]

[74] Vindmølleindustrien. Denmark - Supplier of Competitive Offshore Wind Solutions. Megavind, December 2010. Available at: http://www.windpower.org/download/953/UK_megavind_report_o k.pdf [Accessed July 14, 2011].

[75] Krohn S. Danish Wind Turbines: An Industrial Success Story, DWIA 2002. Available at: http://www.vindselskab.dk/media-

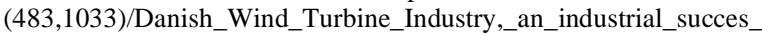
story.pdf [Accessed July 17, 2011].

[76] Megavind. Danmarks fremtid som kompetencecentrum for vindkraft. Megavind, 2007. Available at: http://www.windpower.org/download/99/danmarks_fremtid_som_kompetencecentr um_for_vindkraft.pdf [Accessed July 17, 2011]

[77] Krohn, S. Wind Energy Policy in Denmark: 25 Years of Success What Now? DWIA 2002. Available at: http://www.vindselskab.dk/media(493,1033)/Wind_energy_policy_in_Denmark\%3A 25_years_of_success_-_what_now\%3F.pdf [Accessed July 17, 2011].

[78] Holm, M. Interview, 2007.

[79] Ryggvik, H.; Engen, O.E. Den skjulte dagsorden, rammer for en alternativ oljepolitikk. SAFE, 2005.

[80] Aftenposten. -SFT ufarlig, December 20, 2006. Available at: http://www.aftenposten.no/nyheter/iriks/article1576341.ece [Acessed May 8, 2008]

[81] Aftenposten.Bellona: -Et svik, May 15, 2007. Available at: http://www.aftenposten.no/nyheter/iriks/article1788351.ece [Acessed July 17, 2011].

[82] Hansen, G. Hopsdal; Steen, M. Vindkraft til havs. CenSES-rapport 1/2011. NTNU: Trondheim, 2011.

[83] Teknisk Ukeblad. 50 urørte vindkrafts $ø$ knader. Dec 7, 2007. Available at: http://www.tu.no/energi/article126511.ece [Accessed July 17, 2011].

[84] Zero. Norge nesten på vind-jumboplass, February 21, 2008. Available at: http://www.zero.no/fornybar/norge-nesten-pa-vind-jumboplass/ [Accessed April 22, 2008].

[85] Vindmølleindustrien. Om Megavind, 2011. Available at: http://www.vindselskab.dk/composite-1609.htm [Accessed July 17, $2011]$.

[86] Jensen, D.B. Vindenergiens udbredelse i Holland og Danmark Samfundsфkonomen, 2002, 3, 32-39.

[87] Lemming, J. Interview, 2008.

[88] Information. Energiaftale med ophævelse af kulstop, nye vindmøller og energibesparelser, February 22, 2008. Available at: http://www.information.dk/155273 [Accessed July 17, 2011]

[89] E24. ESA sier ja til månelandingen på Mongstad, July 16, 2008. Available at: http://e24.no/makro-og-politikk/article2543066.ece [Accessed July 17, 2011].

[90] Information. Kul på, June, 2008. Available at: http://www.information.dk/160755 [Accessed July 17, 2011]

[91] Moen, E. 'Næringsn $\varnothing y$ tralitet' eller næringsavvikling? Discussion Paper; BI Handelshøyskolen: Oslo, 2005.

[92] International Herald Tribune Denmark leads the way in green energy - to a point, 21 March 2007. Available at: http://www.iht.com/articles/2007/03/21/business/green1.php [Aces-sed July 17, 2011].

[93] Vindmølleindustrien. Vind eller forsvind i den globale $\emptyset$ konomi, 2004. Available at: http://www.vindselskab.dk/media-(277,1030)/vind eller forsvind.pdf [Accessed July 17, 2011].

[94] Vindmølleindustrien. Vindstyrke 50, 2007. Available at: http://windpower.customers.composite.net/media(1574,1030)/Vinds tyrke_50.pdf [Accessed July 17, 2011].

[95] Knagenhjelm, M; Sataøen, H.L. Barrierer mot vindkraft. VF-notat. Vestlandsforsking: Sogndal, 2005.

[96] DONG; Vattenfall; Danish Energy Authority; Danish Forest and Nature Agency. Danish Offshore Wind, 2006. Available at http://www.ens.dk/graphics/Publikationer/Havvindmoeller/havvind moellebog nov 2006 skrm.pdf [Accessed July 17, 2011].

[97] Megawatt. Vindmølleindustriens nyhedsmagasin, May(1), 2007 Available at: http://www.windpower.org/download/116/Megawatt 2007 1.pdf [Accessed July 17, 2011].

[98] Teknisk Ukeblad. -Energibransjen er for liten. 2007, 38, 30-31.

[99] Midttun, A. The negotiated political economy of a heavy industrial sector. Scand. Polit. Stud., 1988, 11 (2), 115-143.

[100] Miljøverndepartement, Det Kongelige. Stortingsmelding nr. 34 (2006-2007): Norsk klimapolitikk. 2007. 
[101] Megawatt. Vindmølleindustriens nyhedsmagasin, December(3), 2007. Available at: http://www.windpower.org/download/115/ Megawatt_2007_3.pdf [Accessed July 17, 2011].
[102] Bellona. Verdens første flytemølle åpnet, August 8, 2009. Available at: http://www.bellona.no/nyheter/nyheter_2009/Verdens_forste_flytemolle_apnet [Accessed July 17, 2011].

(C) Espen Moe; Licensee Bentham Open.

This is an open access article licensed under the terms of the Creative Commons Attribution Non-Commercial License (http://creativecommons.org/licenses/by-nc/3.0/) which permits unrestricted, non-commercial use, distribution and reproduction in any medium, provided the work is properly cited. 